\title{
An Index of Unnecessary Deaths
}

\author{
LILLIAN GURALNICK and ANN JACKSON
}

M ORE THAN 100 years ago, Dr. William Farr, superintendent of the Statistical Department of the Registrar General's Office of England, suggested the following standard for the measurement of "unnatural" deaths (1).

The mortality of the districts of England in which the sanitary conditions are the least unfavourable can be employed as a standard measure. . . . The mortality of the English people, in very variable but generally favourable conditions, does not exceed 17 in 1,000 deaths. The deaths of 17 persons in 1,000 may therefore be considered, in our present imperfect state, natural deaths, and all deaths above that number may be referred to artificial causes. . . . 17 in 1,000 is supplied as a standard by experience. Here we stand upon the actual. Any deaths in people exceeding 17 in 1,000 annually are unnatural deaths. . . .

In the United States today the most unfavorable death rate is far below 17 deaths per 1,000 population, but the gap between the highest and lowest rates by State still approximates the range observed by Farr for the districts of England. The range of death rates for 1959-61, the most recent period for which detailed figures by State are available, is shown in table 1.

The same kind of observation can be made for the causes of death. The range of rates for 1959-61 by State for some of the important causes of death is shown in table 2.

Thus, it is relevant to the assessment of health problems today to repeat Farr's calculation of "unnatural" deaths. We have attempted to reproduce it here, based on the more detailed data now available to the statistician. In the present context, unnecessary deaths are defined as the deaths in a State or city in excess of the number that would have occurred had the most favorable rates for any State or city prevailed in the same year. The most favorable rates have been selected arbitrarily as the average of the five lowest rates for each age group, by cause, when the

The authors are statisticians, National Center for Health Statistics, Public Health Service. rates are ranked by State. For 1959-61, these calculated standard low rates for age groups between 1 and 74 years are shown in table 3 . The low average death rate for infants under 1 year

Table 1. Highest and lowest death rates for any State for 1959-61, by age groups

\begin{tabular}{|c|c|c|}
\hline \multirow{2}{*}{ Age group (years) } & \multicolumn{2}{|c|}{$\begin{array}{c}\text { Death rate per } \\
100,000 \text { population }\end{array}$} \\
\hline & $\begin{array}{l}\text { Highest } \\
\text { for any } \\
\text { State }\end{array}$ & $\begin{array}{l}\text { Lowest } \\
\text { for any } \\
\text { State }\end{array}$ \\
\hline $\begin{array}{l}\text { Under } 1 \text {. } \\
1-4 \\
5-14 \\
15-244 \\
25-34 \\
35-44 \\
45-544 \\
55-64 \\
65-74\end{array}$ & $\begin{array}{r}13,996.6 \\
178.4 \\
91.1 \\
177.3 \\
240.1 \\
549.8 \\
1,115.5 \\
2,402.6 \\
4,277.9\end{array}$ & $\begin{array}{r}1,997.9 \\
77.2 \\
36.7 \\
59.4 \\
94.2 \\
219.0 \\
568.2 \\
1,349.8 \\
3,128.0\end{array}$ \\
\hline
\end{tabular}

${ }^{1}$ Per 100,000 live births.

Table 2. Highest and lowest death rates for any State for 1959-61, by cause of death

\begin{tabular}{|c|c|c|}
\hline \multirow{2}{*}{ Cause of death 1} & \multicolumn{2}{|c|}{$\begin{array}{c}\text { Death rate per } \\
100,000 \text { population }\end{array}$} \\
\hline & $\begin{array}{l}\text { Highest } \\
\text { for any } \\
\text { State }\end{array}$ & $\begin{array}{l}\text { Lowest } \\
\text { for any } \\
\text { State }\end{array}$ \\
\hline $\begin{array}{l}\text { Tuberculosis, all forms } \\
\text { (001-019) } \\
\text { Malignant neoplasms, etc. } \\
\quad(140-205) \\
\text { Diabetes mellitus (260) } \\
\text { Major cardiovascular-renal } \\
\text { diseases (330-334, 400-468, } \\
\text { 592-594) } \\
\text { Influenza (480-483) } \\
\text { Pneumonia (490-493) } \\
\text { Cirrhosis of liver (581) } \\
\text { Accidents (E800-E962) } \\
\text { Suicide (E970-E979) }\end{array}$ & $\begin{array}{r}654.6 \\
5.8 \\
49.6 \\
27.2 \\
106.7 \\
26.2\end{array}$ & $\begin{array}{r}154.3 \\
.5 \\
18.9 \\
4.7 \\
\text { 35. } 1 \\
6.4\end{array}$ \\
\hline
\end{tabular}

1 Seventh revision of International Lists, 1955. 
of age, used without regard to cause, was 2,133 per 100,000 live births. Deaths at 75 years of age and over were not included in the calculation.

The unnecessary deaths in the community among persons under 75 years of age can be obtained as a total of the excess at each age, or for each cause of death. The same figure will be reached, of course, but, as a byproduct of the calculation, a figure can also be obtained for the unnecessary deaths for each age group, for each of the selected causes, or for each age-cause specific combination. The number of excess deaths expressed as a percentage of the number of

Table 3. Average of 5 lowest death rates ${ }^{1}$ by State for selected causes and age groups, United States, 1959-61

\begin{tabular}{|c|c|c|c|c|c|c|c|c|}
\hline \multirow{2}{*}{ Cause of death 2} & \multicolumn{8}{|c|}{ Age groups (years) } \\
\hline & $1-4$ & $5-14$ & 15-24 & $25-34$ & $35-44$ & $45-54$ & $55-64$ & $65-74$ \\
\hline $\begin{array}{l}\text { Tuberculosis, all forms }(001-019) \\
\text { Malignant neoplasms, etc. }(140-205) \\
\text { Diabetes mellitus (260) } \\
\text { Major cardiovascular-renal diseases (330-334, } \\
\text { 400-468, 592-594) } \\
\text { Influenza and pneumonia (480-493) } \\
\text { Cirrosis of liver (581) } \\
\text { Accidents (E800-E962) } \\
\text { Suicide (E970-E979) } \\
\text { All other causes }\end{array}$ & $\begin{array}{l}\mathbf{0} \\
\mathbf{6 .} 5 \\
0 \\
1.3 \\
7.9 \\
\mathbf{0} \\
\mathbf{2 0 .} 6 \\
\mathbf{3 4 . 2}\end{array}$ & $\begin{array}{l}0 \\
5.5 \\
0 \\
1.4 \\
1.1 \\
0.8 \\
12.8 \\
0 \\
11.9\end{array}$ & 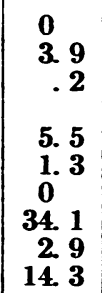 & \begin{tabular}{r|}
12.8 \\
1.6 \\
16.3 \\
1.8 \\
23.6 \\
7.1 \\
20.2
\end{tabular} & $\begin{array}{r}0.9 \\
38.8 \\
2.6 \\
68.8 \\
4.0 \\
4.4 \\
23.2 \\
8.3 \\
32.6\end{array}$ & $\begin{array}{r}2.4 \\
123.5 \\
5.9 \\
249.8 \\
9.8 \\
12.1 \\
29.5 \\
13.8 \\
66.2\end{array}$ & $\begin{array}{r}\text { 5. } 8 \\
\text { 303. } 8 \\
21.7 \\
696.8 \\
\text { 23. } \\
13.3 \\
\text { 33. } 9 \\
15.8 \\
138.6\end{array}$ & $\begin{array}{r}9.7 \\
562.6 \\
54.1 \\
1,875.9 \\
63.9 \\
17.2 \\
66.7 \\
13.9 \\
292.7\end{array}$ \\
\hline
\end{tabular}

1 Rates per 100,000 population in each specified group.

2 Seventh revision of International Lists, 1955.

Table 4. Excess ${ }^{1}$ deaths by age and cause of death, North Dakota and Texas, 1959-61

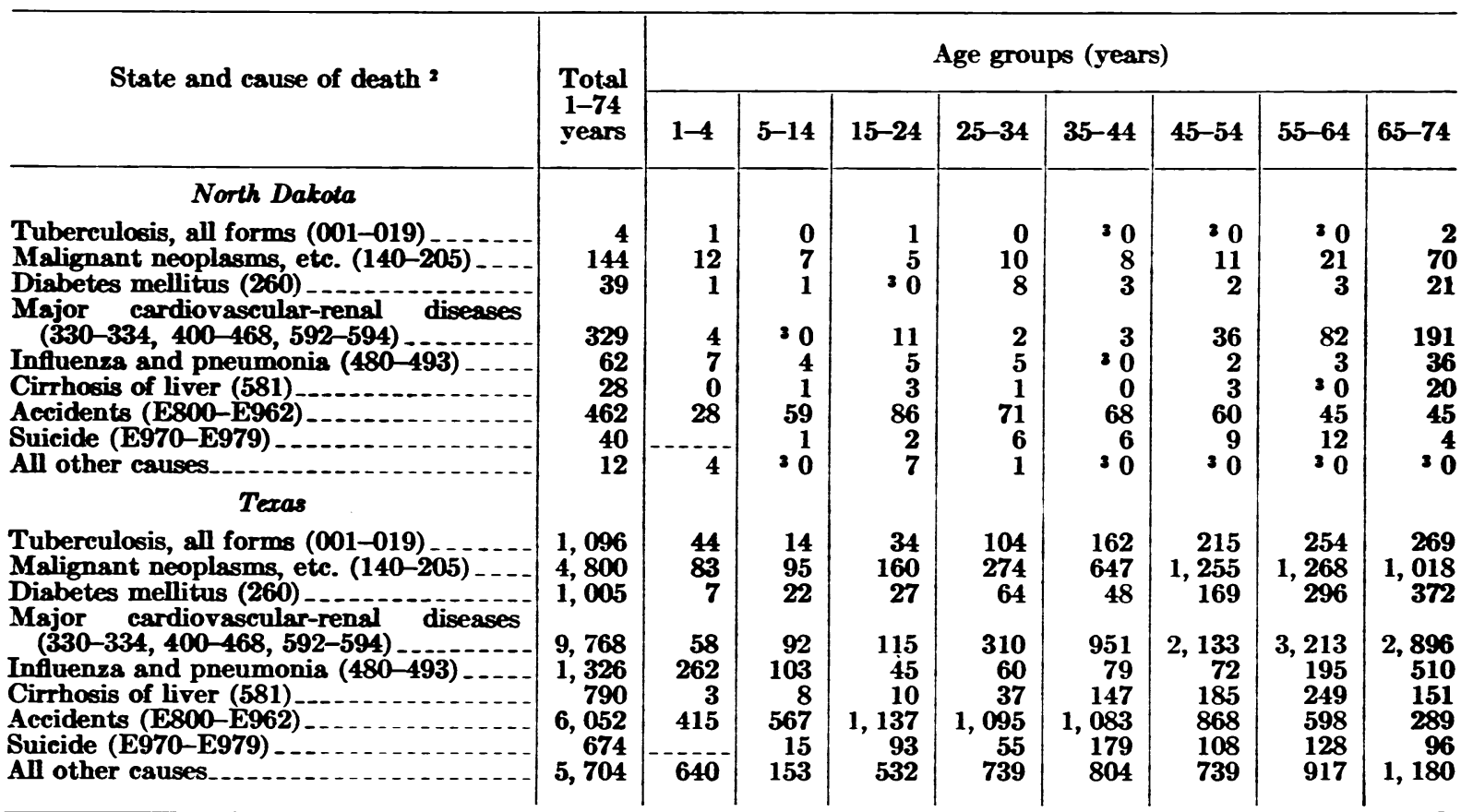

1 Excess is actual number of deaths minus expected number, based on rates in table 3.

2 Seventh revision of International Lists, 1955.

3 Rate is actually lower than figure shown in table 3 ; therefore, actual number of deaths is lower than expected number of deaths. The difference is treated as zero. 
Table 5. Index of unnecessary deaths (UDI) by age and cause of death, North Dakota and Texas, 1959-61

\begin{tabular}{|c|c|c|c|c|c|c|}
\hline \multirow[b]{2}{*}{ Cause of death ${ }^{1}$ and age groups (years) } & \multicolumn{3}{|c|}{ North Dakota } & \multicolumn{3}{|c|}{ Texas } \\
\hline & $\underset{\text { (percent) }}{\mathrm{UDI}}$ & $\begin{array}{l}\text { Excess } \\
\text { deaths }\end{array}$ & $\begin{array}{l}\text { Actual } \\
\text { deaths }\end{array}$ & $\begin{array}{c}\text { UDI } \\
\text { (percent) }\end{array}$ & $\begin{array}{l}\text { Excess } \\
\text { deaths }\end{array}$ & $\begin{array}{l}\text { Actual } \\
\text { deaths }\end{array}$ \\
\hline All causes, all ages under 75 years. & 13. 0 & 1,250 & 9,638 & 23. 1 & 36,201 & 156,596 \\
\hline $\begin{array}{l}\text { Deaths under } 1 \text { year } \\
\text { Tuberculosis, all forms (001-019) } \\
\text { Malignant neoplasms, etc. (140-205) } \\
\text { Diabetes mellitus (260) } \\
\text { Major cardiovascular-renal diseases }(330-334,400-468, \\
\text { 592-594) } \\
\text { Influenza and pneumonia }(480-493) \\
\text { Cirrhosis of liver (581) } \\
\text { Accidents (E800-E962) } \\
\text { Suicide (E970-E979) } \\
\text { All other causes (residual) }\end{array}$ & $\begin{array}{r}10.8 \\
17.4 \\
8.6 \\
25.5 \\
\text { 7. } 7 \\
27.4 \\
26.9 \\
48.9 \\
26.5 \\
1.3\end{array}$ & $\begin{array}{r}130 \\
4 \\
144 \\
39 \\
329 \\
62 \\
28 \\
462 \\
40 \\
12\end{array}$ & $\begin{array}{r}4,258 \\
226 \\
104 \\
944 \\
151 \\
913\end{array}$ & $\begin{array}{l}15.1 \\
36.3 \\
41.4 \\
45.4 \\
28.5 \\
29.3\end{array}$ & $\begin{array}{r}4,986 \\
1,096 \\
4,800 \\
1,005 \\
9,768 \\
1,326 \\
790 \\
6,052 \\
674 \\
5,704\end{array}$ & $\begin{array}{r}20,873 \\
1,479 \\
26,416 \\
2,605 \\
\\
64,528 \\
3,652 \\
1,906 \\
13,323 \\
2,362 \\
19,452 \\
\end{array}$ \\
\hline 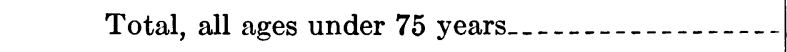 & 13. 0 & 1,250 & 9,638 & 23. 1 & 36,201 & 156,596 \\
\hline 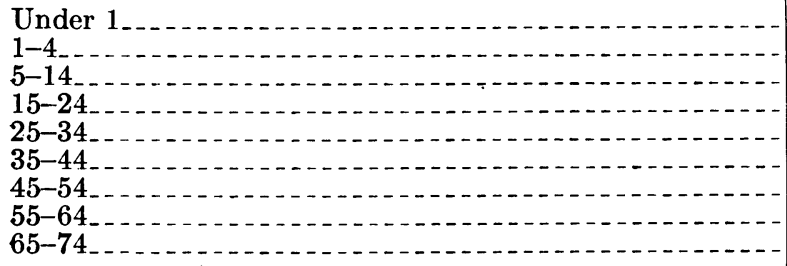 & $\begin{array}{r}\text { 10. } 8 \\
\text { 30. } 0 \\
\text { 35. } 8 \\
41.5 \\
\text { 36. } 5 \\
\text { 18. } 4 \\
10.6 \\
\text { 7. } 9 \\
10.4\end{array}$ & $\begin{array}{r}130 \\
57 \\
73 \\
120 \\
104 \\
88 \\
123 \\
166 \\
389\end{array}$ & $\begin{array}{r}1,200 \\
190 \\
204 \\
289 \\
285 \\
479 \\
1,163 \\
2,094 \\
3,734\end{array}$ & $\begin{array}{l}\text { 23. } 9 \\
43.6 \\
\text { 35. } 2 \\
\text { 45. } 7 \\
\text { 46. } 4 \\
\text { 37. } 8 \\
\text { 26. } 4 \\
\text { 20. } 1 \\
\text { 13. } 4\end{array}$ & $\begin{array}{l}4,986 \\
1,512 \\
1,069 \\
2,153 \\
2,738 \\
4,100 \\
5,744 \\
7,118 \\
6,781\end{array}$ & $\begin{array}{r}20,873 \\
3,470 \\
3,041 \\
4,714 \\
5,900 \\
10,835 \\
21,739 \\
35,481 \\
50,543\end{array}$ \\
\hline
\end{tabular}

${ }_{1}^{1}$ Seventh revision of International Lists, 1955.

deaths occurring in the group described (either by age, cause, area, or any combination of the defined factors) is the index of unnecessary deaths (UDI).

The calculations for the index (or indices) are shown for two States, North Dakota and Texas, in tables 4 and 5. As shown in table 5, 13 percent of the deaths in North Dakota would not have occurred if the death rates for that State had been consistently as low as the most favorable figures to be found in the United States. In Texas, under these same circumstances, 23 percent of the deaths could have been prevented. By cause, the greatest percentage of excess deaths for Texas occurred from tuberculosis, while in North Dakota, accidents produced the largest relative gap from the minimum rates. Similarly, by age, young adults 15-24 years of age suffered the greatest ratio of excess deaths in North Dakota. In Texas, the UDI was about 4.6 percent for two age groups-15-24 and 25-34 years.
The same proportions of excess deaths reflect different numbers of deaths for each State. A UDI of 13 percent for North Dakota (table 5) resulted from 1,250 excess deaths. However, if Texas had had a UDI of 13 percent, there would have been an excess of 20,357 deaths. The UDI expresses the difference in rates between the defined standard and those of the State or city for which the computations are made. Both the concept and the computation are exceedingly simple. The figures obtained can serve to remind us that now, even as in the 19th century, we must contend with gross inequalities in mortality throughout the United States.

\section{REFERENCE}

(1) Humphreys, N. A., editor: Vital statistics: A memorial volume of selections from the reports and writings of William Farr, M.D., D.C.L., C.B., F.R.S., late superintendent of the Statistical Department of the Registrar General's Office, England. Office of the Sanitary Institute, Iondon, 1885. 


\section{An Ultrafiltration Apparatus for Concentration Dialysis}

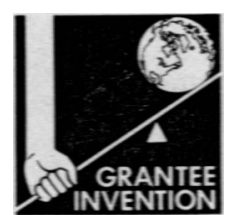

BIOLOGICAL research frequently involves the concentration of protein and other macromolecules from large volumes of fluid. This ultrafiltration device permits the rapid concentration and separation of proteins from smaller molecules such as polypeptides, salts, amino acids, and water without danger of denaturation. Dialysis of the retentate can be accomplished simultaneously.

The apparatus consists of dialyzing tubing $(A)$ of $24 \mathrm{~A}$. mean pore size, open at either end and supported by a porous sintered stainless steel cylinder of 20 microns mean pore size (see figure). The bottom of the dialyzing tubing is closed by a Delrin plastic plug $(B)$ fitted with a venting valve. The top is similarly closed by a Delrin plastic plug with a fitting for introducing sterile medical nitrogen gas or additional protein solution from a reservoir placed in series with the apparatus and the nitrogen tank.

If retention of the smaller molecules that pass through the dialyzing tubing and the porous sintered stainless steel cylinder is desired, a glass jacket is incorporated in the design (see figure), and the filtrate collected in the space between the glass jacket and the stain-

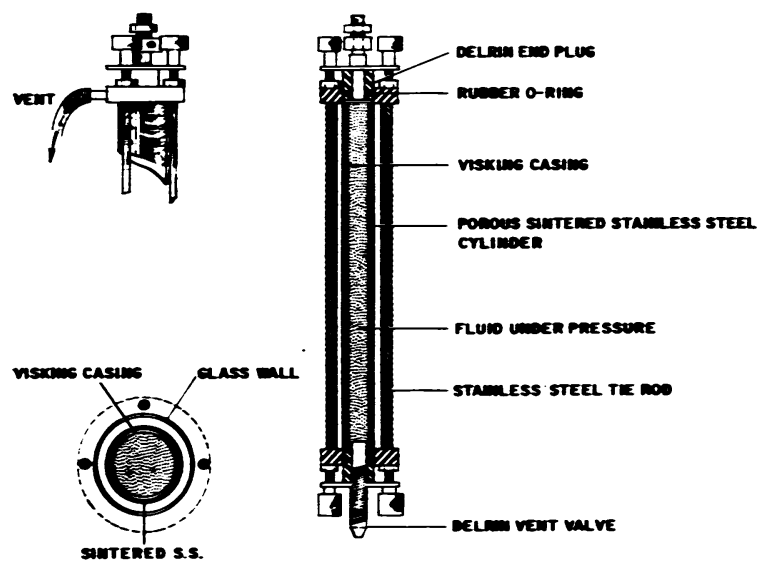

NIL_Saravis ultrafiltration apparatus less steel cylinder. Thus, a sample can be deproteinized without resorting to the use of protein precipitants.

A protein solution is concentrated by placing it within the supported dialyzing tubing and applying a gas pressure of 80 to 100 p.s.i. While the protein solution is being concentrated, salts are being removed from the exterior surface of the membrane by dialysis in water or a buffer of the desired ionic strength and $\mathrm{pH}$, thus preventing the possible denaturation of proteins lying on the interior of the membrane. When the desired volume of retentate is achiered, the pressure is dropped to 4 p.s.i., and final dialysis occurs.

Rates of filtration for a $140 \mathrm{ml}$. capacity unit with an initial surface area of $37 \mathrm{sq}$. in. and at 100 p.s.i. are $53 \mathrm{ml}$. per hr. for 0.5 percent human albumin; $72 \mathrm{ml}$. per $\mathrm{hr}$. for normal human urine (overnight collection); and $71 \mathrm{ml}$. per hr. for normal human plasma diluted 1:10.

The literature shows that compared with other methods of concentrating proteins such as lyophylization, pervaporation, and dialysis against carbowax, ultrafiltration has been superior for protein recovery in the native state $(1$, 2). For many years ultrafiltration has been used by the author to concentrate plasma fractions, urines, and chromatographic eluates without significant losses of biological activity or protein.

At the present time only Visking cellulose tubing is generally available for the ultrafiltration apparatus. However, with the further development of membrane technology more rapid and selective partitioning membranes should become available.

A useful adjunct to the ultrafiltration apparatus is a solenoid valve $(C)$ to control the flow of nitrogen gas. The electrical current to the valve is governed by a clock $(D)$ setting the functioning time of the valve. During this time gas passes freely from the nitrogen tank into the ultrafiltration device. At the conclusion of a timed run the gas flow is shut off and 
the residual gas in the inner chamber is automatically released until 4 pounds of pressure remain. Dialysis may then be completed and the contents subsequently vented through the bottom plug.-Calvin A. Saravis, Ph.D., director, immunochemical laboratory, Protein Foundation, Jamaica Plain, Mass. This invention was developed in part under Public Health Service grant No. HE-6302. The apparatus was developed in conjunction with the National Instrument Laboratories, Inc., Rockville, Md.

\section{REFERENCES}

(1) Miyastao, F., and Pollak, V. F.: Serum proteins in urine: An examination of the effects of some methods used to concentrate the urine. J Lab Clin Med 67 : 1036 (1966).

(2) Park, M. Y., Saravis, C., and Blatt, W. F.: Recovery of gonadotrophins from human male urine by ultrafiltration and kaolin adsorption procedures. J Endocr 34:273-274, February 1966.

\section{EQUIPMENT REFERENCES}

(A) Visking dialyzing tubing, Union Carbide Corp., Chicago, Ill.

(B) Plastic plug, Delrin, Carmer Co., Hanover, N.J.

(C) Solenoid value S-33801-25R, Airmatic Inc., Cleveland, Ohio.

(D) Timer 2E027, Dayton Electric Manufacturing Co., Chicago, Ill.

\section{Education Notes}

Cornell Department of Water Resources Engineering. A new department which unifies graduate and undergraduate teaching and research activities in water resources engineering has been formed at Cornell University.

Its curriculum includes fluid mechanics, hydraulics, hydrology, air and water resources engineering, sanitary engineering, and water resources planning and management. Theoretical and experimental aspects of fundamental phenomena, process and system design, and application of mathematical modeling, digital computer techniques, economic theory, and systems analysis methodology will be applied to problems in environmental and water resource systems.

Financial support for graduate study is available. Additional information may be obtained from Charles D. Gates, Chairman, Department of Water Resources Engineering, Hollister Hall, Cornell University, Ithaca, N.Y. 14850.

Doctorate in Medical Care Organization. Fellowships for a program of study leading to a Ph.D. degree in medical care organization are available from the University of Michigan.

Designed to be completed in 3 years, the program is intended to provide competence in medical care, relevant aspects of sociology and economics, and re- search methods. Stipends, which begin at $\$ 2,400$, are supplemented by an additional $\$ 500$ for each dependent and full tuition. They are increased every year.

Students with a bachelor's or an advanced degree in the social or health sciences can apply by writing to Benjamin J. Darsky, Chairman, Doctoral Program in Medical Care Organization, School of Public Health, University of Michigan, Ann Arbor 48104.

Environmental Health Fellowships. Under an interdepartmental program to give students broad training for careers in research, teaching, and practice in environmental health, the Consolidated University of North Carolina (Chapel Hill and Raleigh campuses) is offering environmental health fellowships for graduate study during 1967-68.

The program is sponsored by the departments of biostatistics, environmental sciences and engineering, and epidemiology of the School of Public Health; the departments of botany, chemistry, city and regional planning, geology, and zoology of the College of Arts and Sciences; the School of Medicine; and the department of food science at North Carolina State University at Raleigh.

The fellowships, provided through the Institute for Environmental Health Studies, include tuition, fees, and a stipend.

Additional information is available from the chairmen of all the departments mentioned, located at Chapel Hill 27514, except for the department of food science at Raleigh 27607. 
Report: Surgeon General's Workshop on Prevention of Disability From Arthritis, PHS Publication No. 1444; April 1966; 105 pages; 75 cents. Provides proceedings of the Workshop on Prevention of Disability From Arthritis which convened May 5-6, 1965, at Airlie House in Warrenton, Va., to discuss the economic, psychological, and sociological effects of crippling arthritis. Discusses such topies as clinical research, education of the public and medical profession, and improved care facilities for persons who suffer from arthritis.

Highlights of the Report: Surgeon General's Workshop on Prevention of Disability From Arthritis. $P H S$ Publication No. 14ff-A; April 1966; 16 pages; 20 cents. Accompanies report of the proceedings of the workshop. Discusses the specific recommendations made by the seven workshop groups, with special emphasis on comprehensive community service programs for persons with arthritis.

Mumps. PHS Publication No. 61, Health Information Series No. 22; revised 1966; leaplet; 5 cents, s2 per 100. Describes the disease, possible complications, tells how it spreads, and warns of dangers to teenagers and adults. Recommends care by physician.

A Manual for Hoopital Central Medical and Surgical Supply Services. PHS Publication No. 950-C15; May 1966; 106 pages; 70 cents. Presents procedures for processing medical and surgical supplies and equipment including illustrations of treatment trays and sets, with their identification, lists of instruments, and a sample index of supplies and equipment. Provides a ready reference for day-to-day activities for supervisors and personnel of the cen- tral medical and surgical supply services. Informs others who are responsible for the operation of such services of the functions and recommended techniques in processing supplies and equipment.

Selected Publications on Environmental Engineering and Food Protection. PHS Publication No. 1499; August 1966, 2d edition; 17 pages. Contains a bibliography of selected publications in the field of environmental engineering and food protection which were developed in the Public Health Service's Division of Environmental Engineering and Food Protection. Includes publications on milk, food, and shellfish sanitation, drinking water supply, special engineering services, urban environmental health planning, and interstate carrier sanitation. Also includes some popular publications for the general public.

Pharmacy Section of the Packaged Disaster Hospital. PHS Publication No. $1071-F-13$; 1966 ; 92 pages; 20 cents. Provides guidance in setting np and operating the pharmacy section of the Packaged Disaster Hospital. Includes information on staffing, a pharmaceutical inventory, and procedures for organixing and dispensing the supplies of this sec tion. Also includes procedures for the legal acquisition, control, and use of narcotics in a civil defense emergency. Persons responsible for the predisaster planning and training connected with setting up and operating the PDH will also find this publication useful.

Obesity and Health. PHS Publication No. $1485 ; 1966 ; 77$ pages; 60 cents. Presents a source book produced by the Public Health Service's Heart Disease Control Branch with the assistance of a group of nonGorernment authorities from the fields of clinical medicine, psychiatry, epidemiology, physiology, biochemistry, public health, nutrition, and dieteties. Presents current information on obesity designed to assist professional health personnel with obesity problems they encounter. Discusses in detail methods of definition and assessment, preralence, health implications, etiology, prevention and control, treatment, and effects of weight rednction. Investigates the particularly complex aspects of obesity which complicate prevention and management, such as age of onset, duration, familial patterns, activity, dietary intake, and emotional stability. Indicates certain groups of the general population that are especially vulnerable to becoming obese.

Establishing the Packaged Disaster Hoopital. PHS Publication No. $1071-F-1$; revised 1966 ; 50 pages; 25 cents. Corers, in general terms, the purpose of the Packaged Disaster Hospital and outlines predisaster preparations necessary for its effective use in a natural or manmade disaster. Explains how the PDH can be used to expand the community hospital to which it is assigned and also how it can be established to function as a separate 200 -bed hospital in an appropriate preselected building and administered by the contracting community hospital. Includes suggestions for floor plans, staffing patterns, and space requirements.

This section cerries ennouncensents of new peldications prepored by the Public Hectith Service and of selected pettications prepored with Federal support.

Unless ofterwise indicated, poblicentions for which prices are quoled ore for sole by the Superintendent of Documents, U.S. Government Printing Onice, Washingtean, D.C. 20402. Orders should be excem panied by cash, check, or money order and should fully identify the publication. Putlic Heath Service poblications wich do not carry price quotutions, es well os single semple copies of those for whidh prices are shown, con be oblained with out charge from the Public Inquiries Branch, Public Health Service, Woshingten, D.C. 20201.

The Public Heaith Service does not spoply poblications other thon its own. 


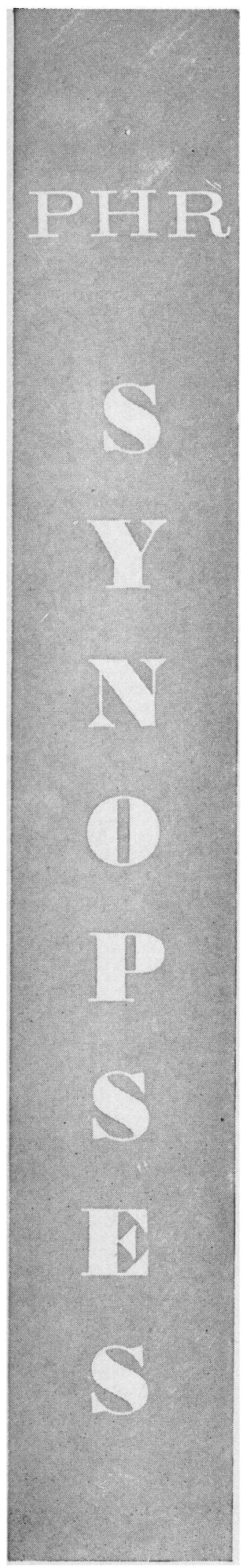

YOUNG, MARJORIE A. C. (Harvard School of Public Health), and HARDY, CAROLYN W.: Youth toward health careers-an evaluation study. Public Health Reports, Vol. 82, February 1967, pp. 99-107.

Health careers programs were evaluated by 525 students in grades 8, 9, and 10 of 14 Massachusetts communities. The programs were evaluated also by school personnel and participating agency staffs. The purpose was to improve the quality of health careers programs so they will compete more favorably with the effectiveness of recruitment programs representing other occupations.

Student career interests were ascertained before and after program attendance and specific factors affecting interest changes were studied. Students in the eighth grade provided the most complete and useful evaluations in terms of relevance of the program to their interests and needs.
The study group evaluating the re sponses of the students and the resource people concluded that community agency and school personnel should be used to plan and evaluate all components of the program and should be used as resource people at all levels. It recommends that future programs should involve pupils from upper elementary and junior high schools and should be presented in the working environments when possible. It further recommends that evaluating each program phase and feeding back to the planners the analyzed and interpreted data is a fundamental prerequisite to continued improvement of program quality.

MYTINGER, ROBERT E. (University of Hawaii) : Barriers to adoption of new programs as perceived by local officers. Public Health Reports, Vol. 82, February 1967, pp. 108-114.

Of the many new programs urged upon local health departments, few are easily and rapidly adopted. Interviews with 40 local health officers in California disclosed a wide array of barriers which are perceived as hampering engagement in seven newer programs-alcoholism, accident prevention, chronic illness detection, home nursing, direct medical care, research, and family planning.

Forces which were perceived by health officers as acting as barriers to engagement were found to fit naturally into five major categories: resistances internal to the health department, those arising from the community, from local government, other agencies, and questions of need or appropriateness.

In only one case, that of family planning, were all barrier categories seen as nearly equally salient in preventing entry into new services. The inhibiting effect of other agencies bears most strongly on engagement in programs of home nursing and provision of direct medical care, while factors internal to the health department seem to control adoption of chronic illness detection programs. Combinations of factors emerge as conditioners of entry into such programs as alcoholism, accident prevention, and research.

Overall, barriers seen as internal to the local health department, and those relevant to the local government, emerged as the strongest inhibitors to engagement in newer programs. Slight differences are seen when local health departments are classified on the basis of their readiness to plan for engagement in a new program, however. In the case of departments reporting no desire to plan or engage in new activities, the inhibiting role of other agencies was reported as the primary reason. When health departments are viewed on the basis of their relative general innovativeness, the least innovative units saw the effect of other agencies as an important inhibitor nearly to the exclusion of all other categories of barriers. 


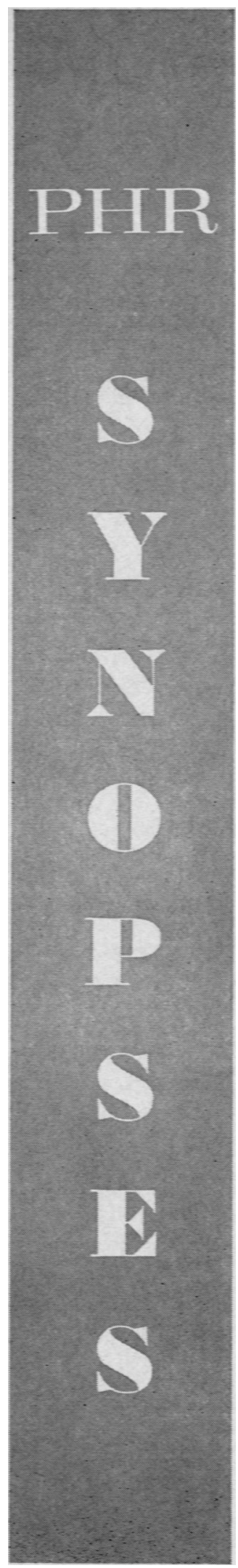

ROBINSON, DJRIX (Mascachmsetts Department of Public Health): Obstetrical care and socid patiens in Metropolitas Boston. Public Hedth Reports, Vol. 82, February 1967, D. 117-126.

A sample of 4,236 certificates of births occurring in Metropolitan Boston in 1962 has provided information on obstetrical care and social patterns for out-of-wedlock and maritally normal births in the metropolitan area. Projected to the total population, this information shows the particular importance of in-migration as a source of potentially high-rist births, with city-born women providing a relatively small proportion of these births. The facilities of the city were overwhelmed by the problem-burdened mothers, normally resident in the suburbs or in more distant nonmetropolitan areas.

Considerable disparity occurred in the use of hospitals for dealing with the high-risk social, economic, and ethnic groups, not all of which could be ascribed to factors of maternal convenience. The deployment of physician skills was determined apparently by social, economic, and ethnic factors rather than by group obstetrical needs and risks.

The findings suggest that closer statistical examinations are needed to reveal the true infiuence of apparently adverse factors associated with infant and maternal mortality. These factors include the way in which medical resources are expended. It is concluded that suburban and rural populations are indebted to the obstetrical resources of the metropolitan core.

ZIMMERMANN, W. J. (Iowa State University of Science and Technology): The incidence of Trichinella spiralis in humans of Iowa. Public Hedth Reports, Vol. 82, February 1967, p. 127-130.

Trichinae larvae or cysts were obtained from 8 (2.8 percent) of 285 human diaphragms examined for Trichimella spiralis infections in Iowa during the period 1961-65. This is in marked contrast to a previons study by the National Institutes of Hearth, Public Health Service, during 1937-44 when 18.9 percent of 37 human diaphragm samples from Iowa contained trichinae.

Examinations were made by the artificial digestion-Baermann and the trichinoscopic methods. All positives were found by the artificial digestionBaermann method, and four were also detected by the trichinoscopic method. Living trichinae were obtained from one diaphragm, while the other seven positive samples contained only calcified cysts.

An age-incidence relationship was obtained with all infections in the older age groups. The eight infected persons ranged from 52 to 84 years of age at death. No definite relationships between sex. residence, and race were established.

BREIDENBACH, A. W. (U.S. Department of the Interior), GUNNERSON, C. G, KAWAHARA, F. K., UCHTENBERG, J. J., and GREEN, R. S.: Chlorinated hydrocarbon pesticides in major river besius, 1957-65. Public Health Reports, Vod. 82, February 1967, pp. 139-156.

The results of the synoptic pesticide surveys of 1964 and 1965 and the eramination of stored carbon adsorption extracts for water years 1958 through 1965 revealed that dieldrin has dominated pesticide occurrences in all river basins since 1958.

Endrin occurrence reached a maximum, particularly in the lower Mississippi River in the fall of 1963 (the first quarter of water year 1964). Since then, endrin levels have decreased. Major fish kills in the lower Mississippi, which had occurred previously during the late fall months, were not reported in 1964 or 1965.

DDT and its cogeners have been fairly common since 1958, and they have been slightly increasing.

A noticeable agreement was seen in data from grab samples and CAM samples in both frequency of occurrence and concentrations of chlorinated hydrocarbon pesticides. This suggests that occasional synoptic surveys may be adequate to characterize pesticide levels on a broad scale in areas where there are no dominant sources of pollution. In areas such as the lower Mississippi River, however, the variability of both dieldrin and endrin clearly requires a greater sampling frequency, possibly including continuous sampling backup with the CAM method. 


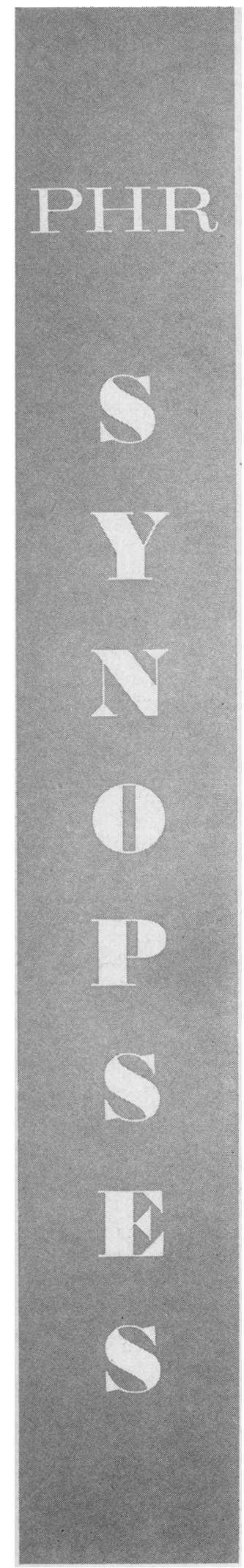

HELSTAD, ARLAN G. (Wisconsin State Laboratory of Hygiene), MANDEL, ADRIAN D., and EVANS, ALFRED S.: Thermostable Clostridium perfringens as cause of food poisoning outbreak. Public Health Reports, Vol. 82, February 1967, pp. 157-161.

A large outbreak of acute gastroenteritis affected 366 college students at the University of Wisconsin, Madison, who ate in a common mess. The main clinical features were diarrhea and abdominal cramps.

The mean incubation was 14 hours and there was a sharp rise and fall of the epidemic curve. Analysis of food questionnaires incriminated gravy as the source of infection with an attack rate of 69.9 percent among those who ate it. Clostridium perfringens was suspected as the cause, and this was confirmed by laboratory studies.

Heat-resistant $C$. perfringens, type A, Hobbs' type 10, was isolated from the stools of 19 of 20 ill students and from none of the 13 stools from healthy students eating in the same mess hall who did not eat the gravy; 1 of the 24 stool specimens from kitchen personnel was positive for the organism. The food samples were negative.

The use of appropriate anaerobic methods of culturing stool specimens and food samples should be a routine part of the bacteriological investigation of a foodborne outbreak of gastroenteritis. This practice would probably lead to increased recognition of outbreaks of food poisoning due to $C$. perfringens and give a truer picture of the organism's relative importance among the causes of foodborne disease in the United States.

EISNER, VICTOR (University of California School of Public Health, Berkeley): Reported juvenile delinquency in San Francisco, 1960-64. Public Health Reports, Vol. 82, February 1967, pp. 163-168.

An analysis of the increase in numbers of juvenile delinquents in San Francisco from 1960 to 1964 showed that approximately two-thirds of the increase was due to measurable population changes. These changes included an increase in the number of juveniles, especially in the highdelinquency ages of 14-19 years, an increase in the proportion of boys, and an increase in the proportion of nonwhite juveniles. The remainder of the increase may be due partly to emigration of middle-class families, but it also suggests that certain juveniles either committed proportionately more offenses in 1964 than in 1960 or were perceived by the police as doing so, or both.

EVANS, ALFRED S. (Yale University School of Medicine): Development of a computer program for the public health laboratory. Public Health Reports, Vol. 82, February 1967, pp. 169-179.

A computer program for analysis of public health laboratory data using an IBM 1410 data processing system has been developed at the Wisconsin State Laboratory of Hygiene. Input data are entered on mark-sense 8 - by 10-inch coding sheets. A six-digit code was evolved for handling microbiological data. Each of five laboratory sections has separate entry forms. On these forms, the 45 columns to the left are used for data common to all sections, while the 45 columns on the right are used for data peculiar to the individual section.

Output data are printed out monthly for bacteriological and cytological data; less frequently in the areas of immunology, rabies, and virology. All positive test results are recorded, as well as negative data for tests of special interest, such as streptococcal sore throats, heterophile antibody, bacterial sensitivities, and cervical cytology ; both positive and negative tests in the immunology, rabies, and virology sections are also recorded. Print-out data include the number of tests and the distribution of persons tested, by county, age, and sex. Tabular data showing the percentage of specific tests positive by month, age and sex of the tested, and the serologic titer are an intrinsic part of the regular report.

Five coders made 218,796 entries during the first year of operation of the computer system, or about 44,000 entries each. Each test in the program cost about 12 cents. 